\title{
Folic Acid-Terminated Poly(2-Diethyl Amino Ethyl Methacrylate) Brush-Gated Magnetic Mesoporous Nanoparticles as a Smart Drug Delivery System
}

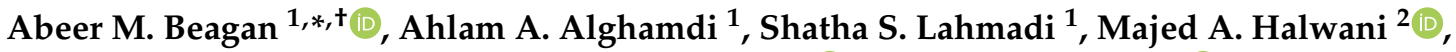 \\ Mohammed S. Almeataq ${ }^{3}$, Abdulaziz N. Alhazaa ${ }^{4} \mathbb{D}$, Khalid M. Alotaibi ${ }^{1}\left(\mathbb{D}\right.$ and Abdullah M. Alswieleh ${ }^{1, *,+}$ \\ 1 Department of Chemistry, College of Science, King Saud University, Riyadh 11451, Saudi Arabia; \\ 437204374@student.ksu.edu.sa (A.A.A.); 438204365@student.ksu.edu.sa (S.S.L.); \\ khalid.m@ksu.edu.sa (K.M.A.) \\ 2 King Abdullah International Medical Research Center, Nanomedicine Department, King Saud bin Abdulaziz \\ University for Health Sciences, Riyadh 11451, Saudi Arabia; halawanima@NGHA.MED.SA \\ 3 King Abdulaziz City for Science and Technology, Riyadh 11451, Saudi Arabia; mmeataq@kacst.edu.sa \\ 4 Department of Physics and Astronomy, College of Science, King Saud University, Riyadh 11451, Saudi Arabia; \\ aalhazaa@ksu.edu.sa \\ * Correspondence: abeagan@ksu.edu.sa (A.M.B.); aswieleh@ksu.edu.sa (A.M.A.) \\ $\dagger$ These authors contributed equally.
}

check for

updates

Citation: Beagan, A.M.; Alghamdi, A.A.; Lahmadi, S.S.; Halwani, M.A.; Almeataq, M.S.; Alhazaa, A.N.; Alotaibi, K.M.; Alswieleh, A.M. Folic Acid-Terminated Poly(2-Diethyl Amino Ethyl Methacrylate) Brush-Gated Magnetic Mesoporous Nanoparticles as a Smart Drug Delivery System. Polymers 2021, 13, 59. https://dx.doi.org/10.3390/ polym13010059

Received: 2 December 2020 Accepted: 23 December 2020 Published: 25 December 2020

Publisher's Note: MDPI stays neutral with regard to jurisdictional claims in published maps and institutional affiliations.

Copyright: (c) 2020 by the authors. Licensee MDPI, Basel, Switzerland. This article is an open access article distributed under the terms and conditions of the Creative Commons Attribution (CC BY) license (https: / / creativecommons.org/ licenses/by/4.0/).

\begin{abstract}
Currently, chemotherapy is an important method for the treatment of various cancers. Nevertheless, it has many limitations, such as poor tumour selectivity and multi-drug resistance. It is necessary to improve this treatment method by incorporating a targeted drug delivery system aimed to reduce side effects and drug resistance. The present work aims to develop $\mathrm{pH}$-sensitive nanocarriers containing magnetic mesoporous silica nanoparticles (MMSNs) coated with $\mathrm{pH}$-responsive polymers for tumour-targeted drug delivery via the folate receptor. 2-Diethyl amino ethyl methacrylate (DEAEMA) was successfully grafted on MMSNs via surface initiated ARGET atom transfer radical polymerization (ATRP), with an average particle size of $180 \mathrm{~nm}$. The end groups of poly (2-(diethylamino)ethyl methacrylate) (PDEAEMA) brushes were converted to amines, followed by a covalent bond with folic acid (FA) as a targeting agent. FA conjugated to the nanoparticle surface was confirmed by X-ray photoelectron spectroscopy (XPS). $\mathrm{pH}$-Responsive behavior of PDEAEMA brushes was investigated by Dynamic Light Scattering (DLS). The nanoparticles average diameters ranged from ca. $350 \mathrm{~nm}$ in basic media to ca. 650 in acidic solution. Multifunctional $\mathrm{pH}$-sensitive magnetic mesoporous nanoparticles were loaded with an anti-cancer drug (Doxorubicin) to investigate their capacity and long-circulation time. In a cumulative release pattern, doxorubicin (DOX) release from nano-systems was ca. $20 \%$ when the particle exposed to acidic media, compared to ca. $5 \%$ in basic media. The nano-systems have excellent biocompatibility and are minimally toxic when exposed to MCF-7, and -MCF-7 ADR cells.
\end{abstract}

Keywords: magnetic mesoporous nanoparticles; $\mathrm{pH}$-responsive polymer brushes; surface functionalization; controlled drug release; anti-cancer drug

\section{Introduction}

Cancer is one of the most common causes of death in the world [1-3]. Nowadays, surgery, radiation, and chemotherapy are widely used to treat most cancers. Surgery and radiotherapy are used for local and non-metastatic cancers. Yet, they are inefficient when cancer has spread throughout the body. Therefore, chemotherapy, where an anti-cancer drug used, is considered to be an effective treatment method. Anti-cancer drugs are toxic molecules that work to stop or slow the growth of cells, whether cancerous or healthy cells [4-8]. Thus, it is very important to develop a new drug delivery system to transport anti-cancer drugs, targeting tumour tissue [9-11]. Various drug delivery systems have been 
developed as a nanocarriers, such as a carbon nanotube [12], nanostructured polymers [13], and mesoporous silica nanoparticles [14-16].

Mesoporous silica nanoparticles (MSNs) have been utilized as a nanocarrier due to their low toxicity, chemically inert, easy chemical modification, and large loading capacity [17-19]. Magnetic mesoporous silica nanoparticles (MMSNs) have been paid attention due to their potential in medical applications, such as magnetic resonance imaging (MRI), magnetic bio-separations, and drug delivery [20-22]. Furthermore, a magnetic mesoporous nanocarrier could target the cancerous tissues inside the body when an external magnetic field is applied [23,24]. Siminzar et al., functionalized the surface of MMSNs with an aptamer (mucin-1) for the delivery of doxorubicin (DOX) to the breast cancer cells [25]. Cai et al., has reported the fabrication of superparamagnetic mesoporous silica nanoparticles coated with MDA-MB-231 cell membranes as a biomimetic drug delivery system [26].

It is necessary to modify the surface of MMSNs with organic molecules such as stimuli polymer brushes to obtain some required properties such as adhesion, charge density, and controlled drug release [27-29]. The end of the polymer chains, in brushes regime, are attached to the particles' surface via physisorption or covalent attachment. Two techniques have been wildly used to grow polymer brushes: reversible addition-fragmentation chain transfer polymerization (RAFT) and atom transfer radical polymerization (ATRP). In stimuli-responsive polymer brushes, the chain conformation change when the surrounding environment has changed, such as light, temperature, and $\mathrm{pH}$ [30-32].

Many studies have been reported on the modification of mesoporous nanomaterials with $\mathrm{pH}$-responsive polymers as gatekeepers [33-35]. Xu et al., loaded quercetin into silica nanoparticles coated with poly (2-(diethylamino)ethyl methacrylate) (PDEAEMA) brushes [36]. The results indicated that the nano-system could be used as potential anticancer drug carriers. Pourjavadi et al., synthesized MMSNs grafted with polymer brushes poly (N-isopropyl acrylamide-co-glycidyl methacrylate) (PNG) modified with hydrazine groups as DOX binding sites [34]. Our previous work reported the synthesis of mesoporous silica grafted with diblock brushes of 2-(tert-butylamino) ethyl meth acrylate-b-poly (ethylene glycol) methyl ether methacrylate as a doxycycline nanocarrier [37].

Most cancer cells are overexpressing some definite receptors on their surfaces. Thus, the surface modification of the nanocarriers with targeting ligands will have a remarkable effect on cancer treatment. The outer surface of mesoporous nanoparticles can be decorated with some targeting molecules such as hormones, antibodies, peptides, and vitamins. Folic acid (FA) could attach selectively to the folate receptor (FR), present on some cancer cells' surface [38,39]. Niedermayer et al., have prepared mesoporous silica nanoparticles attached with $\mathrm{pH}$-responsive poly (2-vinylpyridine) (PVP) and folic acid as a targeted molecule [40]. Folic acid-polyethylenimine (FA-PEI) coated mesoporous nanoparticles were synthesized as a smart drug carrier by Park et al. [41] Li et al., have developed mesoporous silica conjugated with a $\mathrm{pH}$ responsive polymer capped with folic acid [42]. It was observed that the fabricated nanoparticles exhibited high loading efficiency with zero pre-release of the drug within $20 \mathrm{~h}$ in normal surroundings. Wu et al., modified magnetic mesoporous silica nanoparticles with poly (ethylene glycol) (PEG) and FA to specifically target cancer cells [43]. They found that the presence of FA on nanoparticles' surface increased the uptake into cancer cells that over-express FA receptors (FRs).

As far as we are aware, very little work has been reported on polymer brush surface modification with targeting molecules. This study aims to develop a new system consisting of targeting a ligand capped $\mathrm{pH}$-responsive polymer grafted into the outer surface of the magnetic mesoporous nanoparticles. This can be achieved by derivatization of halogen groups on the surface of the polymer brushes with folic acid. In this study, magnetic mesoporous silica nanoparticles (MMSNs) were coated with pH-responsive poly (2-(diethylamino) ethyl methacrylate) (PDEAEMA) brushes via an ARGET ATRP technique. The end group of PDEAMA brushes was derivatized with folic acid (FA) for tumourtargeted drug delivery via the folate receptor, Scheme 1 . The nanocarriers were loaded 
with Doxorubicin (DOX) and the release behavior was investigated. The nano-systems were subjected to MCF-7 and MCF-7 ADR cells for a cytotoxicity test. The characteristics of the samples were studied using various techniques such as scanning electron microscopy (SEM), transmission electron microscopy (TEM) and X-ray photoelectron spectroscopy (XPS).

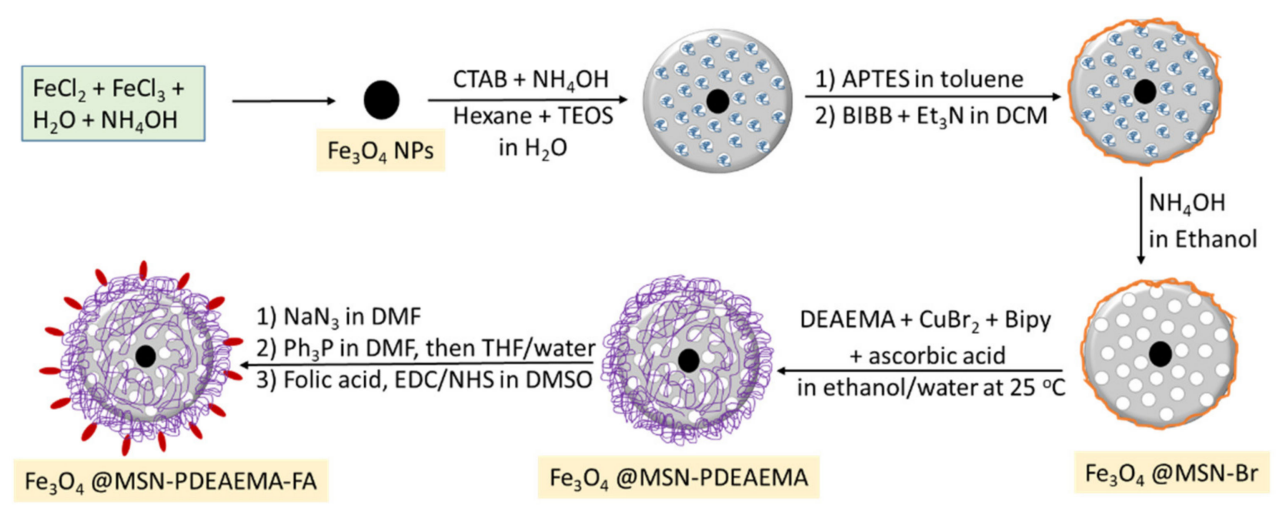

Scheme 1. Synthesis procedure for poly(2-(diethylamino) ethylmethacrylate) brushes capped folic acid grafted on magnetic mesoporous silica nanoparticle (MMSNs) surfaces via SI-ARGET ATRP.

\section{Materials and Methods}

\subsection{Materials}

Deionized water was obtained from Elga Pure Nanopore System. Ammonium hydroxide (28 wt \%, CAS 1336-21-6), 3-aminopropyltriethoxysilane (APTES, >98\%, CAS 919-30-2), N-cetyltrimethylammonium bromide (CTAB, 98\%, CAS 57-09-0), methanol (99.8\% HPLC grade, CAS 67-56-1), tetraethylorthosilicate (TEOS, 98\%, CAS 78-10-4), ethanol (99.8\%, HPLC grade, CAS 64-17-5), pyridine (analytical grade, CAS 110-86-1), dichloromethane (DCM, HPLC grade, CAS 75-09-2), 2,2'-bipyridyl (bipy, 99\%,CAS 366-18-7), isopropanol (99.8\%, CAS 67-63-0), 2-bromo-2-methylpropionyl bromide (BIBB, 98\%, CAS 20769-85-1), (2-(diethylamino) ethylmethacrylate) (PDEAEMA, 99\%, CAS 2867-47-2), triphenylphosphine (pph3, 99\%, CAS 603-35-0), dimethylformamide (99.9\%, HPLC grade, CAS 68-12-2), n-hexane (HPLC grade, CAS 68-12-2), sodium Hydroxide (CAS 1310-73-2), and folic acid (FA, CAS 59-30-3) were purchased from Sigma-Aldrich. Cupric bromide $\left(\mathrm{CuBr}_{2}, 98 \%\right.$, CAS 7789-45-9) was purchased from BDH chemicals. Sodium azide (NaN3, 99\%, CAS 26628-22-8), triethylamine (TEA, 99\%, CAS 121-44-8), ferric chloride (99\%, CAS 7705-08-0), and ferrous chloride (99\%, CAS 7758-94-3) were purchased from Loba Chemie. Tetrahydrofuran (THF, CAS 109-99-9) were purchased from Nexgen chemicals. Ammonium nitrate $\left(\mathrm{NH}_{4} \mathrm{NO}_{3}, 99 \%\right.$, CAS 6484-52-2) was obtained from Winlab chemicals reagents fine chemicals. N-Hydroxysuccinimide (NHS, CAS 6066-82-6), doxorubicin hydrochloride (DOX.HCl, CAS 25316-40-9), dimethylsulfoxide (DMSO, CAS 67-68-5), and N, N'-Di cyclohexylcarbodiimide (DCC, CAS 538-75-0) were obtained from Tokyo Chemical Industry. Sodium chloride (CAS 7440-23-5), potassium chloride (CAS 7440-09-7), disodium hydrogen phosphate (CAS 7558-79-4), potassium dihydrogen phosphate (CAS 7778-77-0), and hydrochloric acid (CAS 7647-01-0) were obtained at Alfa Aesar. All the chemicals were used as received.

\subsection{Methods of Preparation}

\subsubsection{Synthesis of Iron Oxide Nanoparticles $\left(\mathrm{Fe}_{3} \mathrm{O}_{4}\right)$}

Iron oxide nanoparticles $\left(\mathrm{Fe}_{3} \mathrm{O}_{4}\right)$ were synthesized according to previous published studies [44,45]. Ferric chloride $\left(\mathrm{FeCl}_{3}, 4.80 \mathrm{~g}\right)$ and ferrous chloride $\left(\mathrm{FeCl}_{2}, 3.12 \mathrm{~g}\right)$ were dissolved in $30 \mathrm{~mL}$ of deionized water under nitrogen atmosphere with stirring at $90{ }^{\circ} \mathrm{C}$. Ammonium hydroxide $(20 \mathrm{~mL})$ was added to the mixture and aged for $150 \mathrm{~min}$. The product was filtered and washed with water and ethanol several times. 


\subsubsection{Synthesis of Iron Oxide Coated with Silica $\left(\mathrm{Fe}_{3} \mathrm{O}_{4} @ \mathrm{MSNs}\right)$}

Iron oxide coated with mesoporouse silica was prepared by suspending $0.5 \mathrm{~g}$ of $\mathrm{Fe}_{3} \mathrm{O}_{4}$ in $160 \mathrm{~mL}$ of deionized water, which was followed by adding $1.0 \mathrm{~g}$ of CTAB at $35^{\circ} \mathrm{C}$. Concentrated ammonia water $(7 \mathrm{~mL}, 28 \mathrm{wt} \%)$ was added. Then a mixture solution of $\mathrm{n}$ hexane $(20 \mathrm{~mL})$ and TEOS $(5 \mathrm{~mL})$ were added into the solution drop wisely within $30 \mathrm{~min}$ under continuous stirring. A homogeneous milky colloidal solution was gradually formed. After stirring for $12 \mathrm{~h}$, the product was collected by filtration and washed several times with deionized water and ethanol. The materials were dried in an oven for $2 \mathrm{~h}$ at $100{ }^{\circ} \mathrm{C}$.

\subsubsection{Synthesis of Amino Functionalized Magnetic Mesoporous Silica $\left(\mathrm{Fe}_{3} \mathrm{O}_{4} @ \mathrm{MSN}-\mathrm{NH}_{2}\right)$}

Amino modification of the silica surface was performed by suspending the obtained $\left(\mathrm{Fe}_{3} \mathrm{O}_{4} @ \mathrm{MSNS}\right)$ nanoparticles $(1.5 \mathrm{~g})$ in a solution of APTES $(0.5 \mathrm{~mL})$ and methanol $(50 \mathrm{~mL})$. The resulting mixture was heated at $70{ }^{\circ} \mathrm{C}$ for $12 \mathrm{~h}$. The nanoparticles were collected by filtration and then washed several times with ethanol.

2.2.4. Synthesis of the ATRP Initiator Functionalized Magnetic Mesoporous Silica $\left(\mathrm{Fe}_{3} \mathrm{O}_{4} @ \mathrm{MSN}-\mathrm{Br}\right)$

$\mathrm{Fe}_{3} \mathrm{O}_{4} @ \mathrm{MSN}-\mathrm{NH}_{2}(1.0 \mathrm{~g})$ was suspended in a mixture of DCM $(25 \mathrm{~mL})$ and triethylamine (1.5 mL). 2- Bromo-2-methylprpionyl bromide $(1.2 \mathrm{~mL})$ in $5 \mathrm{~mL}$ of DCM was added drop wise into the mixture and stirred at room temperature for $48 \mathrm{~h}$. The solid was then separated by filtration and washed several times with DCM and ethanol.

\subsubsection{Formation of Channels $\left(\mathrm{Fe}_{3} \mathrm{O}_{4} @ \mathrm{MSN}-\mathrm{Br}\right)$}

The surfactant was removed by ionic exchange using a solution of ammonium nitrate $(10 \mathrm{mg} / \mathrm{mL})$ in ethanol $(95 \%)$ at $70{ }^{\circ} \mathrm{C}$ overnight under stirring. The nanoparticles were collected and washed with ethanol.

2.2.6. Synthesis of Poly(2-Dimethyl Amino Ethyl Methacrylate) (PDMAEMA) Brushes Coated Magnetic Mesoporous Silica $\left(\mathrm{Fe}_{3} \mathrm{O}_{4} @\right.$ MSN-PDMAEMA)

In small vial, $\mathrm{Fe}_{3} \mathrm{O}_{4} @ \mathrm{MSN}-\mathrm{Br}(0.4 \mathrm{~g})$ was suspended in a degassed mixture of ethanol $(4 \mathrm{~mL})$ and deionized water $(1 \mathrm{~mL})$. A mixture of 2-dimethyl amino ethyl methacrylate (DMAEMA) (2 mL), $\mathrm{CuBr}_{2}(0.0009 \mathrm{~g})$, and of 2,2 bipy (0.0067 g) dissolved in ethanol $(8 \mathrm{~mL})$ and water $(2 \mathrm{~mL})$ was added to the suspension and degassed for $15 \mathrm{~min}$. Ascorbic acid $(0.0076 \mathrm{~g})$ was added to the polymerization mixture and stirred for $3 \mathrm{~h}$. The solid was washed with $0.01 \mathrm{M}$ of $\mathrm{HCl}$ solution and ethanol several times.

\subsubsection{Synthesis of $\left(\mathrm{Fe}_{3} \mathrm{O}_{4} @ M S N-P D M A E M A-\mathrm{NH}_{2}\right)$}

$\mathrm{Fe}_{3} \mathrm{O}_{4} @$ MSN-PDMAEMA (200 mg) was suspended with $2 \mathrm{~mL}$ of degassed dimethylformamide (DMF) and kept under $\mathrm{N}_{2}$. Sodium azide $\left(\mathrm{NaN}_{3}\right)$ was dissolved in degassed DMF to make a solution of $2 \mathrm{M}$. Sodium azide $\left(\mathrm{NaN}_{3}\right)$ solution $(5 \mathrm{~mL})$ was added to $\mathrm{Fe}_{3} \mathrm{O}_{4} @ M S N-P D M A E M A$ under $\mathrm{N}_{2}$ atmosphere and $60^{\circ} \mathrm{C}$ for $18 \mathrm{~h}$.

$\mathrm{Fe}_{3} \mathrm{O}_{4} @$ MSN-PDMAEMA- $\mathrm{N}_{3}(200 \mathrm{mg})$ was suspended with $2 \mathrm{~mL}$ of degassed dimethylformamide (DMF) and kept under $\mathrm{N}_{2}$. Triphenylphosphine $\left(\mathrm{PPh}_{3}\right)$ was dissolved in degassed DMF to make a solution of $2 \mathrm{M}$. Triphenylphosphine $\left(\mathrm{PPh}_{3}\right)$ solution $(5 \mathrm{~mL})$ was added to $\mathrm{Fe}_{3} \mathrm{O}_{4} @$ MSN-PDMAEMA-N $\mathrm{N}_{3}$ under an $\mathrm{N}_{2}$ atmosphere and $60^{\circ} \mathrm{C}$ for $18 \mathrm{~h}$.

The product was suspended in a mixture of water and tetrahydrofuran under nitrogen atmosphere for $18 \mathrm{~h}$ at $40^{\circ} \mathrm{C}$. The final product was washed with water and ethanol and dried at $60^{\circ} \mathrm{C}$ for $2 \mathrm{~h}[46,47]$.

\subsubsection{Nanoparticles Modification with Folic Acid ( $\left.\mathrm{Fe}_{3} \mathrm{O}_{4} @ M S N-P D M A E M A-F A\right)$}

Folic acid $(2.5 \mathrm{~g})$ was dissolved in a mixture of DMSO $(50 \mathrm{~mL})$ and triethylamine $(1.3 \mathrm{~mL})$. DCC $(2.3 \mathrm{~g})$ and NHS (1.3 g) were added to the mixture and stirred over night at room temperature in the dark. The by-product is removed by filtration using glass fiber paper [48]. $\mathrm{Fe}_{3} \mathrm{O}_{4} @ M S N-P D M A E M A-\mathrm{NH}_{2}(0.5 \mathrm{~g})$ was added to $25 \mathrm{~mL}$ of the filtrated 
solution and stirred overnight at room temperature. The final product was filtered and washed with DMSO and ethanol.

\subsection{Measurement and Characterization}

Scanning Electron Microscopy (SEM) images were taken by JEOL JSM-7610F at $15 \mathrm{KV}$. Transmission Electron Microscopy (TEM) images were taken by A JEOL JEM-1400 at $100 \mathrm{KV}$. Infrared spectra were obtained using a Perkin-Elmer Spectrum BX instrument with a resolution of $4 \mathrm{~cm}^{-1}$ in the region of $400-4400 \mathrm{~cm}^{-1}$. A Micromeritics Gemini 2375 volumetric analyzer was used to measure the surface area using nitrogen physisorption isotherms. Thermogravimetric Analysis (TGA) was utilized on a Perkin-Elmer Pyris 1 TGA instrument with a temperature range of $25-1000{ }^{\circ} \mathrm{C}$ at a heating rate of $20^{\circ} \mathrm{C} / \mathrm{min}$. In terms of X-ray photoelectron spectroscopy (XPS), the samples were analyzed by JPS-9030 JOEL. In a prior analysis, the sample was etched for $20 \mathrm{~s}$ by Ar gas in an Ultra High Vacuum Chamber (UHV) with pressure $10^{-9}$ torr. Malvern instruments (Zetasizer Nano ZS) was used to measure the particle size at different $\mathrm{pH}$ values. SpectraMax Plus 384 Microplate Reader was used to obtain UV spectra.

\subsection{Drug Loading and Release}

In the loading procedure: nanoparticles $(1 \mathrm{mg})$ were dispersed in $1 \mathrm{~mL}$ of different concentration Dox solution and $1 \mathrm{~mL}$ of PBS. The suspension's $\mathrm{pH}$ was adjusted to 3 by adding $\mathrm{HCl}(0.1 \mathrm{M})$ and stirred for $24 \mathrm{~h}$ at $25{ }^{\circ} \mathrm{C}$ in the dark condition. The $\mathrm{pH}$ change to 8 by adding $\mathrm{NaOH}(0.1 \mathrm{M})$ and stirred for $3 \mathrm{~h}$. The solid was combined to determine the concentration of unloaded Dox [49]. The encapsulation efficiency (EE) and the loading capacity (LC) were estimated according to the following equations.

$$
\begin{aligned}
\mathrm{EE} \% & =(\text { Weight of loaded drug } / \text { Weight of drug in feed }) \times 100 \\
\mathrm{LC} \% & =(\text { Weight of loaded drug } / \text { Weight of Nanoparticles }) \times 100
\end{aligned}
$$

In the release procedure, $0.25 \mathrm{mg}$ of Dox@ $\mathrm{Fe}_{3} \mathrm{O}_{4} @ \mathrm{MSN}-\mathrm{PDMAEMA}$ or Dox@ $\mathrm{Fe}_{3} \mathrm{O}_{4}$ @MSN-PDMAEMA-FA was suspended at $37^{\circ} \mathrm{C}$ in a buffer solution $(1 \mathrm{~mL})$ at a different $\mathrm{pH}$ under constant shaking $(220 \mathrm{rpm})$. At a specific time, the nanoparticles were separated by centrifugation, the supernatant $(1 \mathrm{~mL})$ was removed, and the amount of released drug was determined by a UV-Vis spectrophotometer. The cumulative weight percent of Dox was calculated using the following equation.

$$
\text { Cumulative weight }(\%)=\frac{\text { weight of drug at specific time points }}{\text { weight of drug in nanoparticles }} \times 100
$$

\subsection{Cytotoxicity Assays}

The cytotoxicity of PDEAEMA-modified hybrid magnetic nanoparticles is tested against cancer cell lines using a presto blue cell viability assay. Breast cancer cells (MCF-7) and resistant cancer cells (MCF-7 ADR) were harvested using $0.25 \%$ trypsin-EDTA. The cancer cells were subjected in 96-well plates at 3000 cells/well in DMEM media and cultured in $5 \% \mathrm{CO}_{2}$ at $37^{\circ} \mathrm{C}$ for 24 h. Various concentration of Free-DOX, Dox@ $\mathrm{Fe}_{3} \mathrm{O}_{4} @ M S N-P D M A E M A, D o x @ \mathrm{Fe}_{3} \mathrm{O}_{4} @ M S N-$ PDMAEMA-FA, $\mathrm{Fe}_{3} \mathrm{O}_{4} @ M S N-P D M A E M A$, and $\mathrm{Fe}_{3} \mathrm{O}_{4} @ M S N-P D M A E M A-F A$ were exposed to a cancer cell line in culture and incubated in $5 \% \mathrm{CO}_{2}$ at $37^{\circ} \mathrm{C}$ for $24 \mathrm{~h}$.

\section{Results and Discussion}

Paramagnetic iron oxide nanoparticles $\left(\mathrm{Fe}_{3} \mathrm{O}_{4}\right)$ were synthesized according to a coprecipitation protocol via mixing two types of iron salts. A SEM image (Figure S1) showed that the nanoparticles are of a spherical shape. Moreover, most of the $\mathrm{Fe}_{3} \mathrm{O}_{4}$ nanoparticles tend to form agglomerates before silica grows on their surface. The size distribution ranged between 10 and $20 \mathrm{~nm}$, which agrees with Enache et al. [45]. 
$\mathrm{Fe}_{3} \mathrm{O}_{4}$ nanoparticles were covered with silica in the presence of CTAB, forming a mesoporous shell (Figure 1). The SEM image showed that the shape of particles was spherical and semi-symmetrical with an average size ranging between 130 and $250 \mathrm{~nm}$ (Figure 1A). The TEM image was acquired for $\mathrm{Fe}_{3} \mathrm{O}_{4} @ \mathrm{MSN}$ as shown in Figure 1B. It can be seen that $\mathrm{Fe}_{3} \mathrm{O}_{4}$ nanoparticles were presented in the middle of $\mathrm{Fe}_{3} \mathrm{O}_{4} @ \mathrm{MSNs}$ with a particle size of $20 \mathrm{~nm}$, which agrees with the SEM image. The presence of surfactant could prevent $\mathrm{Fe}_{3} \mathrm{O}_{4}$ aggregation in the synthesis of the MSNs shell. The size of $\mathrm{Fe}_{3} \mathrm{O}_{4} @ \mathrm{MSNs}$ was estimated to be ca. $200 \mathrm{~nm}$.
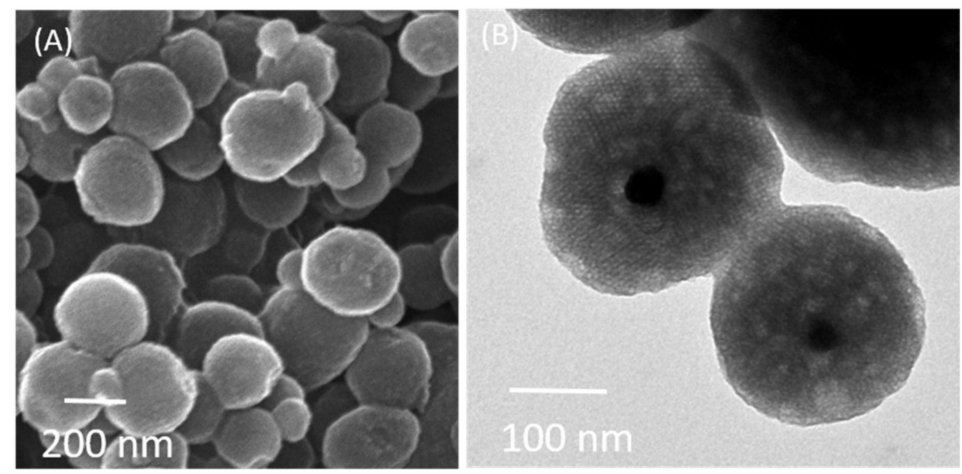

Figure 1. Microscopic images of magnetic mesoporous silica nanoparticles ( $\left.\mathrm{Fe}_{3} \mathrm{O}_{4} @ \mathrm{MSNs}\right)$ : (A) SEM image and (B) TEM images.

Magnetic mesoporous silica nanoparticles were successfully coated with PDEAEMA brushes via SI-ATRP, as shown in SEM and TEM images (Figure 2). The average diameter of $\mathrm{Fe}_{3} \mathrm{O}_{4} @ M S N-P D E A E M A$ was ca. $250 \mathrm{~nm}$ with spherical morphology compared to 200-nm none-coated nanoparticles. PDEAEMA brushes' thickness was estimated to be $50 \mathrm{~nm}$, as illustrated in Figure 2A. The TEM image showed the size of $\mathrm{Fe}_{3} \mathrm{O}_{4} @ \mathrm{MSN}-\mathrm{PDEAEMA}$ was ca. $260 \mathrm{~nm}$, which is in good agreement with the SEM image.

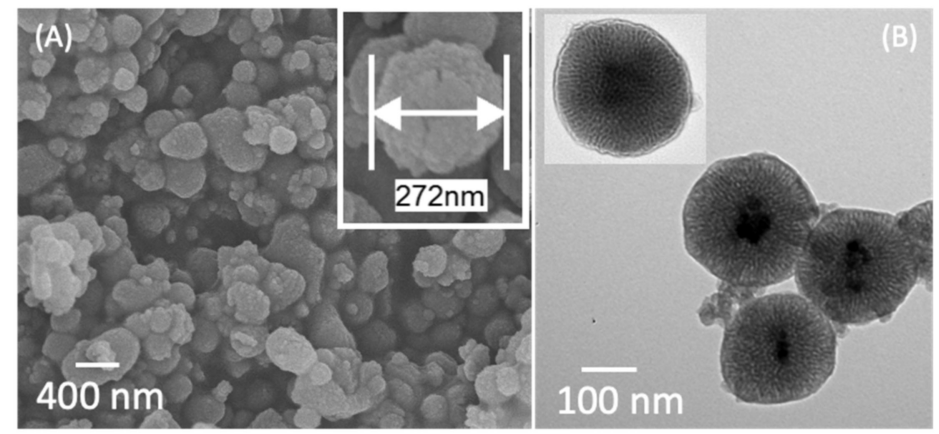

Figure 2. (A) SEM image and (B) TEM images of magnetic mesoporous silica nanoparticles coated with PDEAEMA.

Brunauer-Emmett-Teller (BET) and Barrett-Joyner-Halenda (BJH) analysis were applied to determine the surface area and pore size of fabricated nanoparticles. Figure 3 reveals nitrogen adsorption-desorption isotherms for $\mathrm{Fe}_{3} \mathrm{O}_{4} @ \mathrm{MSNs}, \mathrm{Fe}_{3} \mathrm{O}_{4} @ \mathrm{MSN}-\mathrm{Br}$, and $\mathrm{Fe}_{3} \mathrm{O}_{4} @ M S N-P D E A E M A$. It can be clearly seen that $\mathrm{Fe}_{3} \mathrm{O}_{4} @ \mathrm{MSN}$ and $\mathrm{Fe}_{3} \mathrm{O}_{4} @ \mathrm{MSN}-\mathrm{Br}$ exhibit type IV physisorption isotherm, indicating mesopores are present in the former. The surface area and pore volume of the $\mathrm{Fe}_{3} \mathrm{O}_{4} @ \mathrm{MSNs}$ were found to be $722 \mathrm{~m}^{2} \cdot \mathrm{g}^{-1}$, $0.92 \mathrm{~cm}^{3} \cdot \mathrm{g}^{-1}$, respectively. The specific surface area was $489 \mathrm{~m}^{2} \cdot \mathrm{g}^{-1}$ for $\mathrm{Fe}_{3} \mathrm{O}_{4} @ \mathrm{MSN}-\mathrm{Br}$, as illustrated in Table $\mathrm{S} 1$. $\mathrm{Fe}_{3} \mathrm{O}_{4} @ \mathrm{MSN}-\mathrm{PDEAEMA}$ exhibits an almost type II isotherm with surface area of $82 \mathrm{~m}^{2} \cdot \mathrm{g}^{-1}$. It would be reasonable to assume that the presence of dense polymer layers on the $\mathrm{Fe}_{3} \mathrm{O}_{4} @ \mathrm{MSN}$ surface could prevent penetration of the $\mathrm{N}_{2}$ gas due to the existence of ATRP initiating groups on the exterior surface of $\mathrm{Fe}_{3} \mathrm{O}_{4} @ \mathrm{MSN}[50,51]$. 


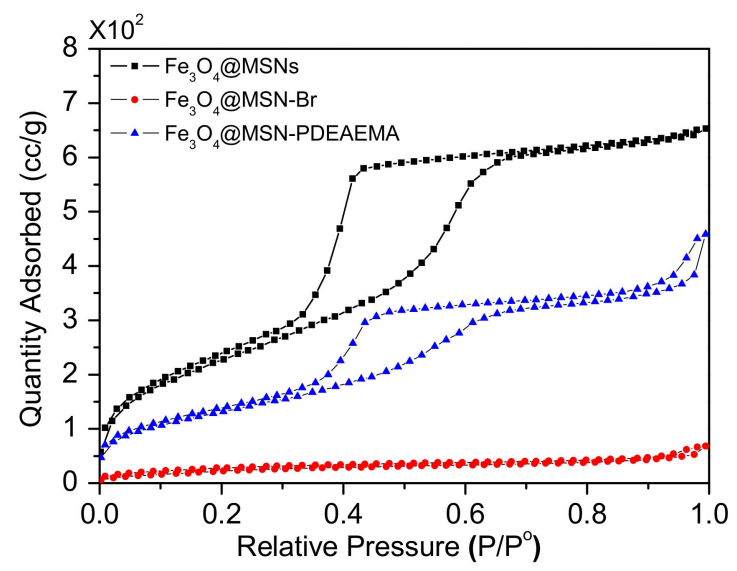

Figure 3. Brunauer-Emmett-Teller of $\mathrm{Fe}_{3} \mathrm{O}_{4} @ \mathrm{MSN}, \mathrm{Fe}_{3} \mathrm{O}_{4} @ \mathrm{MSN}-\mathrm{Br}$, and $\mathrm{Fe}_{3} \mathrm{O}_{4} @ \mathrm{MSN}-\mathrm{PDEAEMA}$.

FTIR spectra of $\mathrm{Fe}_{3} \mathrm{O}_{4} @ M S N s$ (with CTAB), $\mathrm{Fe}_{3} \mathrm{O}_{4} @ M S N s, \mathrm{Fe}_{3} \mathrm{O}_{4} @ M S N-B r$, and $\mathrm{Fe}_{3} \mathrm{O}_{4} @ M S N-P D E A E M A$ are presented in Figure S2. For all samples, the absorption peaks at 1084 and $1230 \mathrm{~cm}^{-1}$ were referred to as Si-O-Si bonds. The absorption peaks at 3450 and $960 \mathrm{~cm}^{-1}$ were assigned to the stretching absorption vibration of $\mathrm{Si}-\mathrm{OH}$. $\mathrm{Fe}_{3} \mathrm{O}_{4} @ M S N s$ (with CTAB), C-H stretching bands were presented at $2930 \mathrm{~cm}^{-1}$ and $2860 \mathrm{~cm}^{-1}$. These peaks disappeared after CTAB extraction. After a polymerization process, a new peak appears at $1720 \mathrm{~cm}^{-1}$ corresponding to $\mathrm{C}=\mathrm{O}$ groups compared to $\mathrm{Fe}_{3} \mathrm{O}_{4} @ \mathrm{MSN}-\mathrm{Br}$.

The successful decoration of magnetic mesoporous silica was evaluated by thermogravimetic analysis (TGA) when heating in an $\mathrm{N}_{2}$ atmosphere to $1000{ }^{\circ} \mathrm{C}$. It was noticed that there was an increase in the weight loss after each synthetic step, which confirms the surface modification of $\mathrm{Fe}_{3} \mathrm{O}_{4} @ \mathrm{MSNs}$ (Figure 4) [37,52,53]. The weight loss of $\mathrm{Fe}_{3} \mathrm{O}_{4} @ \mathrm{MSN}-$ $\mathrm{NH}_{2}$ with the surfactant has three mass loss steps. The first step started from the ambient to ca. $215^{\circ} \mathrm{C}$, which ascribed to the water desorption and dehydration from nanoparticles. The second loss step was from ca. 230 to $320^{\circ} \mathrm{C}$, which was assigned to the degradation of the surfactant and organic groups in a silane monolayer. The third step started from ca. $350{ }^{\circ} \mathrm{C}$, which attributed to the nanoparticles' dehydroxylation. The total weight loss of $\mathrm{Fe}_{3} \mathrm{O}_{4} @ \mathrm{MSN}-\mathrm{NH}_{2}$ with CTAB was estimated to be ca. $28 \%$. Similar behavior was observed when the amino functionalized $\mathrm{Fe}_{3} \mathrm{O}_{4} @ M S N-\mathrm{NH}_{2}$ with CTAB reacted with BIBB. The weight loss of initiated nanoparticles was ca. $27 \%$ after removing CTAB. The surfactant weight in the nanoparticles was estimated to be ca. 13\%. After the growth of PDEAEMA, the weight loss was three mass loss steps. The first step started from the ambient to ca. $250{ }^{\circ} \mathrm{C}$, corresponding to the water desorption and dehydration. The second loss mass step ranged from ca. 300 to $450{ }^{\circ} \mathrm{C}$, which was assigned to the decomposition of PDEAEMA chains. The last weight loss step was around $480^{\circ} \mathrm{C}$, which attributed to the nanoparticles dehydroxylation. The polymer weight attached to Fe@MSNs' surface was estimated to be ca. $9 \%$.

X-ray photoelectron spectroscopy was performed to study the surface modification of $\mathrm{Fe}_{3} \mathrm{O}_{4} @$ MSN-PDEAEMA (Figure 5). The C1s spectrum of the PDEAEMA brush grafted on $\mathrm{Fe}_{3} \mathrm{O}_{4} @ M S N$ s was fitted with three peaks at $284.8 \mathrm{eV}, 286.1 \mathrm{eV}$, and $288.6 \mathrm{eV}$ with a ratio of 4.5:3.8:1, corresponding to the $\mathrm{C}-\mathrm{H}, \mathrm{C}-(\mathrm{N}, \mathrm{O})$, and $\mathrm{O}=\mathrm{C}-\mathrm{O}$, respectively, in good agreement with a theoretical ratio of 5:4:1 (Figure $5 \mathrm{~A}$ ) [52,53]. After aminating the end group of the polymer chains, there is no difference in C1s spectrum of PDEAEMA, as shown in Figure 5B. After surface derivatization with folic acid, a peak was fitted at $\sim 286.5 \mathrm{eV}$, corresponding to the $\mathrm{C}-\mathrm{O}$ bonds' present organic layer. Moreover, the peak intensity at $288.5 \mathrm{eV}$ increased, which confirmed the successful attachment of folic acid (Figure 5C). 


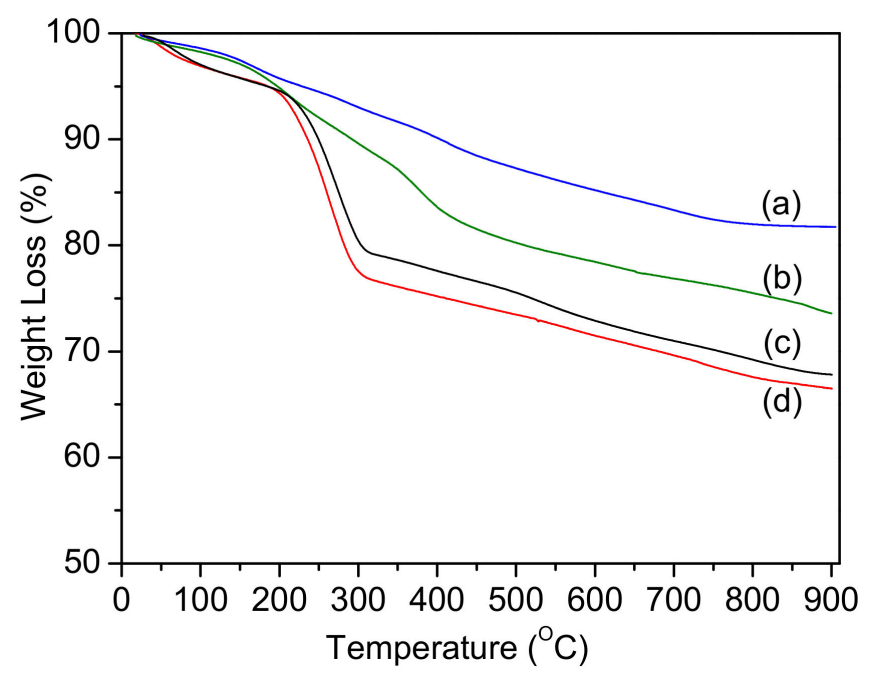

Figure 4. TGA curves of $\mathrm{Fe}_{3} \mathrm{O}_{4} @ \mathrm{MSN}-\mathrm{NH}_{2}$ (with CTAB) (c), $\mathrm{Fe}_{3} \mathrm{O}_{4} @ \mathrm{MSN}-\mathrm{Br}$ (with CTAB) (d), $\mathrm{Fe}_{3} \mathrm{O}_{4} @ \mathrm{MSN}-\mathrm{Br}(\mathrm{a})$, and $\mathrm{Fe}_{3} \mathrm{O}_{4} @ \mathrm{MSN}-\mathrm{PDEAEMA}(\mathrm{b})$.
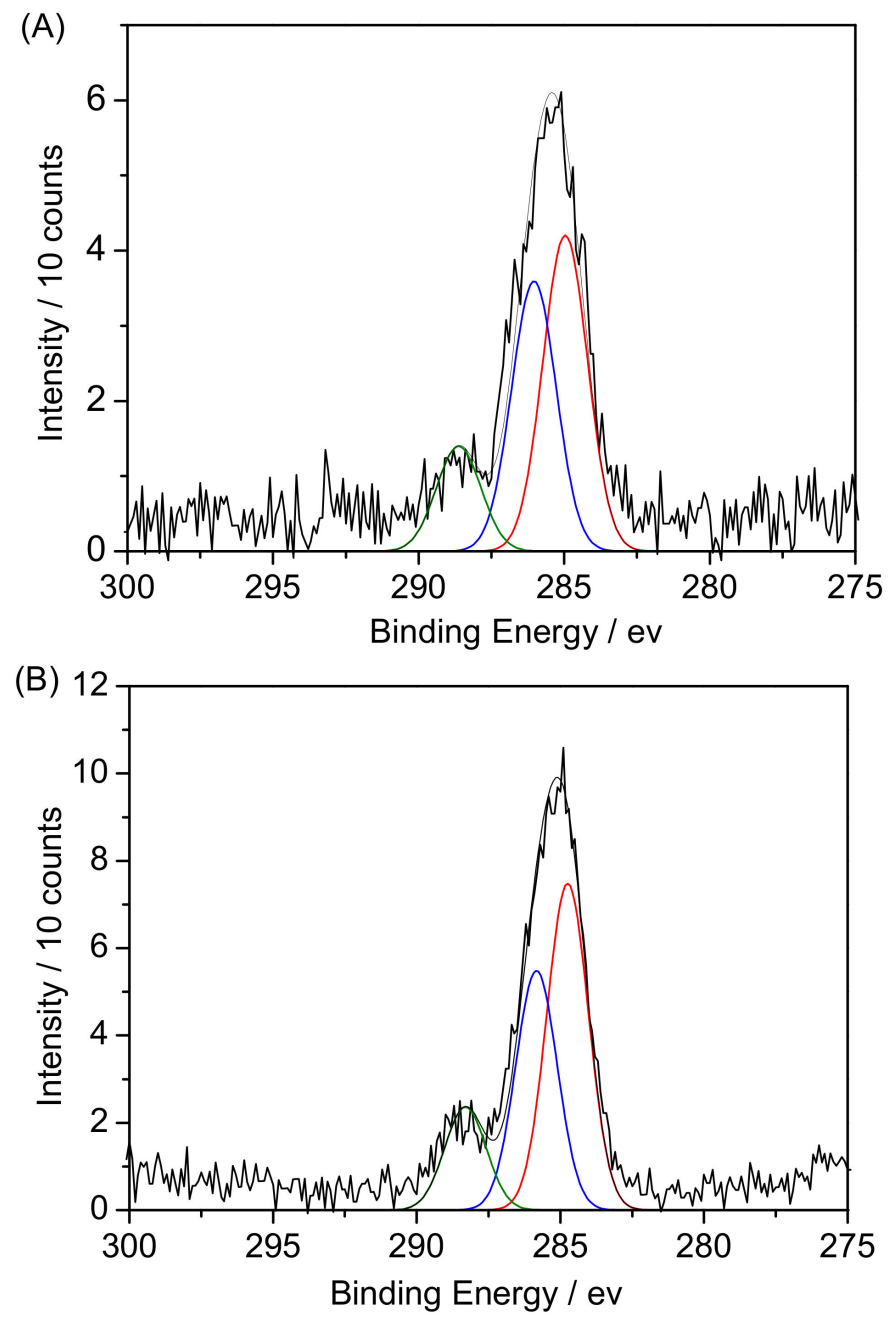

Figure 5. Cont. 


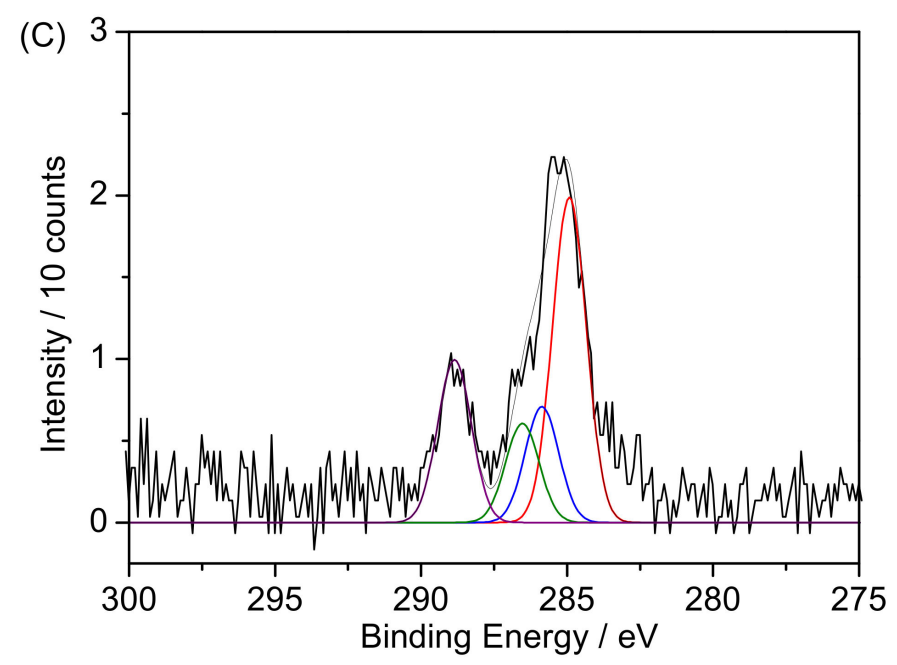

Figure 5. XPS spectra of $\mathrm{C} 1$ s peaks for: (A) $\mathrm{Fe}_{3} \mathrm{O}_{4} @ M S N-P D E A E M A,(B) \mathrm{Fe}_{3} \mathrm{O}_{4} @ M S N-P D E A E M A-$

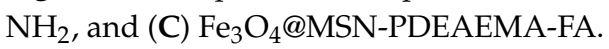

Hydrodynamic sizes of $\mathrm{Fe}_{3} \mathrm{O}_{4} @ M S N-P D E A E M A$ was measured in PBS at different $\mathrm{pH}$ values by DLS, as shown in Figure 6. The size of $\mathrm{Fe}_{3} \mathrm{O}_{4} @ M S N-P D E A E M A$ change as the $\mathrm{pH}$ values change due to the protonation or deprotonation of amino groups at PDEAEMA

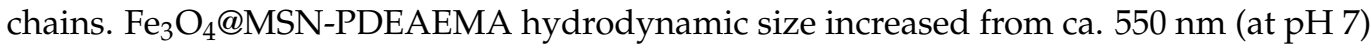
to $750 \mathrm{~nm}$ (at $\mathrm{pH}$ 4) due to the protonation process of amino groups causing a hydrophilic characteristic. In an alkaline solution, the amino groups in PDEAEMA segments were deprotonated and became a hydrophobic polymer, leading to a decrease in the size of particles from ca. $550 \mathrm{~nm}$ to ca. $350 \mathrm{~nm}$ at $\mathrm{pH} 8$.

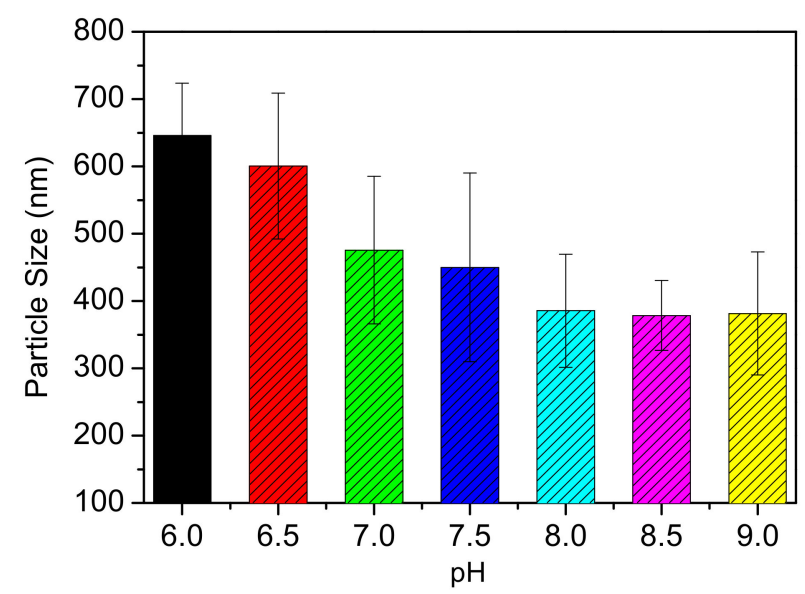

Figure 6. Illustration the change in size of $\mathrm{Fe}_{3} \mathrm{O}_{4} @ \mathrm{MSN}-\mathrm{PDEAEMA}$ as function of $\mathrm{pH}$ value at $20^{\circ} \mathrm{C}$.

$\mathrm{Fe}_{3} \mathrm{O}_{4} @ M S N-P D E A E M A$ and $\mathrm{Fe}_{3} \mathrm{O}_{4} @ M S N-P D E A E M A-F A$ loading capacities were measured by UV-Vis spectroscopy at $480 \mathrm{~nm}$. At $\mathrm{pH}=3$, PDEAEMA chains are protonated and expanded, leading to open the pores and allow Dox to pass into the pores. At $\mathrm{pH}=8$, PDEAEMA chains collapsed and were hosted into pores. As observed, the amounts of drug storage increased as Dox concentrations increased. At the same concentration, there was no

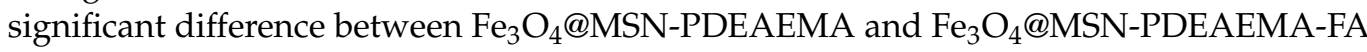
in the loading capacity (see Table S2 and Figure S3).

The drug release from $\mathrm{Fe}_{3} \mathrm{O}_{4} @ M S N-P D E A E M A$ and $\mathrm{Fe}_{3} \mathrm{O}_{4} @ M S N-P D E A E M A-F A$ were investigated at different $\mathrm{pH}$ buffer solutions. The results show that Dox's cumulative release from both nano-systems was higher in acidic solution than basic media (Figure 7). At $\mathrm{pH}>7$, the amount of drug release was less than $6 \%$ within $48 \mathrm{~h}$, due to the collapse process of the PDEAEMA segments. After $48 \mathrm{~h}$, an insignificant difference in cumulative 
Dox release was observed for both nano-systems at a pH of 5 and 6.5, which was ca. $16 \%$ and ca. 13\%, respectively. Protons in the solution can diffuse through PDEAEMA chains easily and protonate the drug's amino group, accelerating the drug release.
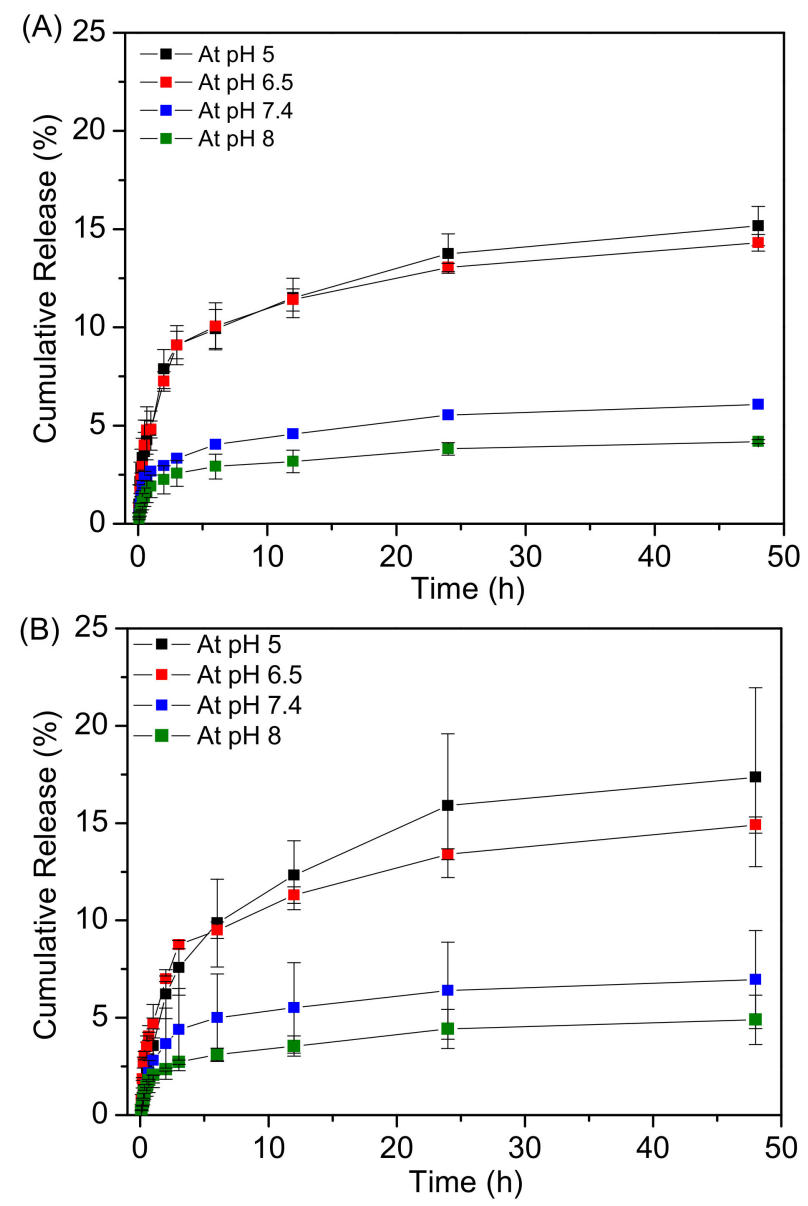

Figure 7. Drug release pattern of DOX loaded in: (A) $\mathrm{Fe}_{3} \mathrm{O}_{4} @ M S N-P D E A E M A$ and (B) $\mathrm{Fe}_{3} \mathrm{O}_{4} @ M S N-$ PDEAEMA-FA in different $\mathrm{pH}$ values at $37^{\circ} \mathrm{C}$.

The cytotoxicity effect of Exposure of Free-DOX, $\mathrm{Fe}_{3} \mathrm{O}_{4} @ M S N-P D M A E M A, \mathrm{Fe}_{3} \mathrm{O}_{4} @ M S N-$ PDMAEMA-FA, Dox@ $\mathrm{Fe}_{3} \mathrm{O}_{4} @ M S N-P D M A E M A$, and Dox@ $\mathrm{Fe}_{3} \mathrm{O}_{4} @ M S N-P D M A E M A-F A$ was assessed using MCF-7-ADR cells MCF-7 cells (Figure 8). No cytotoxic effect was observed against MCF-7-ADR cells and MCF-7 cells when unloaded nano-systems were exposed to the cells, even at a high concentration, as shown in Figure S4. Folic acid modified $\mathrm{Fe}_{3} \mathrm{O}_{4} @ M S N-P D M A E M A$ mitigated the cytotoxic effects. Considerable cell damage or cell death when Free-DOX, Dox@Fe $\mathrm{F}_{3} @ \mathrm{MSN}-\mathrm{PDMAEMA}$, or Dox@ $\mathrm{Fe}_{3} \mathrm{O}_{4} @ M S N-$ PDMAEMA-FA was exposed with MCF-7-ADR cells MCF-7 cells for $24 \mathrm{~h}$ (Figure 8A,B). It is clear that a significant decrease in cell viability was found at all concentrations of Free-

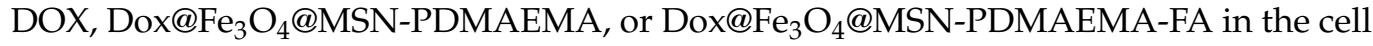
lines. Cell viability systematically decreased with increasing concentration of Free-DOX,

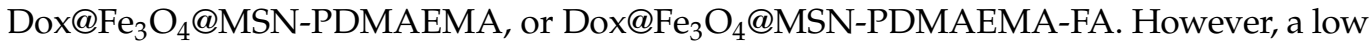
level $(>60 \%)$ of cell viability can be seen only in a very low concentration of $\mathrm{Dox}_{\mathrm{F}} \mathrm{Fe}_{3} \mathrm{O}_{4} @ \mathrm{MSN}-$ PDMAEMA-FA, compared to Free-DOX, Dox@ $\mathrm{Fe}_{3} \mathrm{O}_{4} @ M S N-P D M A E M A$. At a high concentration, Dox@ $\mathrm{Fe}_{3} \mathrm{O}_{4} @ M S N-P D M A E M A$ show the higher cytotoxic effect than Dox@ $\mathrm{Fe}_{3} \mathrm{O}_{4} @ M S N-$ PDMAEMA-FA in MCF-7-ADR and MCF-7 cell lines. 


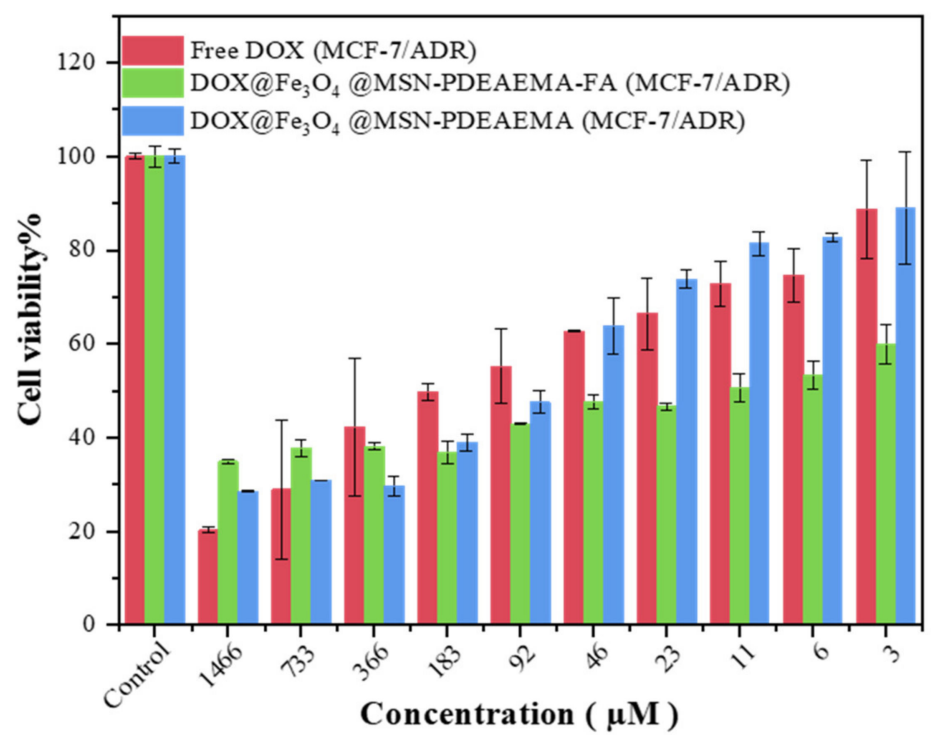

(A)

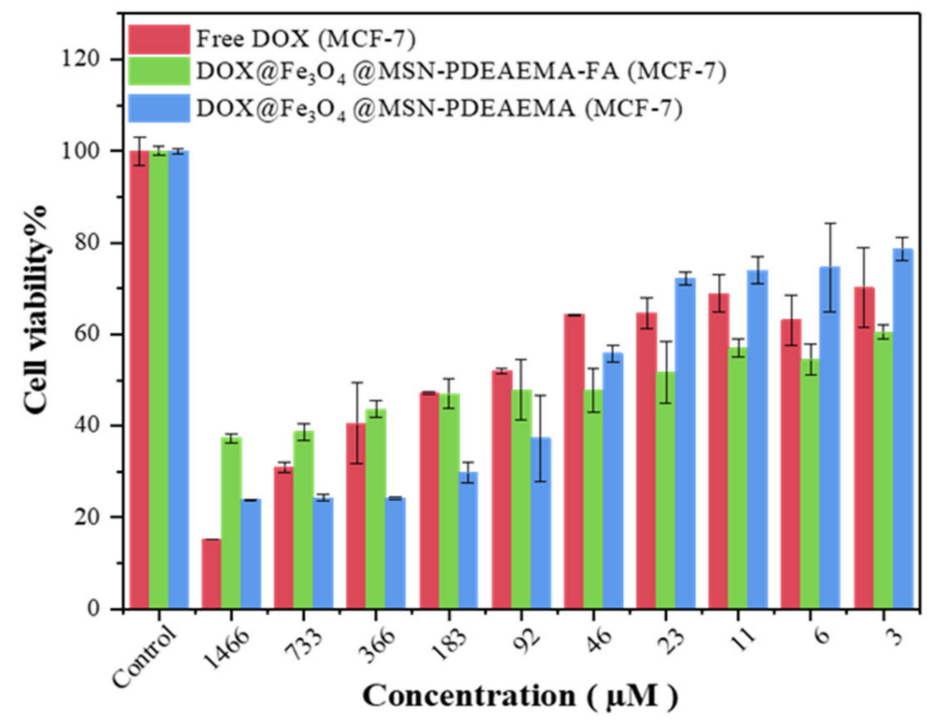

(B)

Figure 8. Cytotoxicity assay of the hybrid magnetic nanostructured. (A) Exposure of Free-

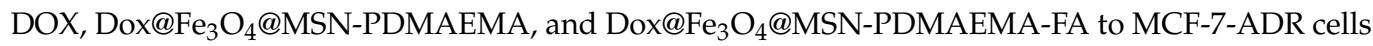
for $24 \mathrm{~h}$. (B) Exposure of Free-DOX, Dox@ $\mathrm{Fe}_{3} \mathrm{O}_{4} @ M S N-P D M A E M A$, and Dox@ $\mathrm{Fe}_{3} \mathrm{O}_{4} @ M S N-$ PDMAEMA-FA to MCF-7 cells for $24 \mathrm{~h}$.

\section{Conclusions}

In summary, we reported folic acid decorated the surface of PDEAEMA-grafted on magnetic mesoporous nanoparticles $\left(\mathrm{Fe}_{3} \mathrm{O}_{4} @ M S N-P D E A E M A\right)$ and modified with folic acid $\left(\mathrm{Fe}_{3} \mathrm{O}_{4} @\right.$ MSN-PDEAEMA-FA) for biomedical application. First, $\mathrm{Fe}_{3} \mathrm{O}_{4}$ cores were coated with mesoporous silica (average size of $180 \mathrm{~nm}$ ), followed by surface functionalized with an ATRP initiator. PDEAEMA brushes were grafted with a dry thickness of $50 \mathrm{~nm}$, via the AGET ATRP technique. The end-groups of PDEAEMA brushes were converted to amines $\mathrm{s}$ using sodium azide and triphenylphosphine. Folic acid was activated using EDC and NHS, and reacted with $\mathrm{Fe}_{3} \mathrm{O}_{4} @ M S N-P D E A E M A-\mathrm{NH}_{2}$. The characteristic of the nanoparticles was identified using SEM, TEM, FT-IR, TGA, and XPS. The nanoparticle's size increased from ca. $350 \mathrm{~nm}$ in basic media, to ca. $750 \mathrm{~nm}$ in acidic media due to the protonation of tertiary amine in the PDEAEMA, as estimated by DLS. The anti-cancer drug (DOX) was loaded within $\mathrm{Fe}_{3} \mathrm{O}_{4} @ M S N-P D E A E M A$ and $\mathrm{Fe}_{3} \mathrm{O}_{4} @ M S N-P D E A E M A-F A$ with 
ca. $66 \%$ loading capacity. The drug release pattern illustrates that Dox was released in a relative control manner from both nano-systems.

Supplementary Materials: The following are available online at https:/ / www.mdpi.com/2073-436 0/13/1/59/s1. Further details of SEM image of $\mathrm{Fe}_{3} \mathrm{O}_{4}$, table of physiochemical data for decorated nanoparticles, FTIR spectra, Dox loading capacity of fabricated nanoparticles, and loading capacities of fabricated nanoparticles.

Author Contributions: A.A.A., S.S.L., M.S.A., A.N.A., K.M.A., and M.S.A. performed the experiments and analyzed the data. M.A.H., A.M.A., and A.M.B. designed the experiments and wrote the manuscript. All authors have read and agreed to the published version of the manuscript.

Funding: This research received no external funding.

Institutional Review Board Statement: Not applicable.

Informed Consent Statement: Not applicable.

Data Availability Statement: The data presented in this study is openly available.

Acknowledgments: The authors extend their appreciation to the Deputyship for Research \& Innovation, "Ministry of Education" in Saudi Arabia for funding this research work through the project number IFKSURG-1441-304.

Conflicts of Interest: The authors declare no conflict of interest.

\section{References}

1. Pérez-Herrero, E.; Fernández-Medarde, A. Advanced targeted therapies in cancer: Drug nanocarriers, the future of chemotherapy. Eur. J. Pharm. Biopharm. 2015, 93, 52-79. [CrossRef]

2. Chauhan, R.; Trivedi, V. Inflammatory markers in cancer: Potential resources. Front. Biosci. (Sch. Ed.) 2020, 12, 1-24. [CrossRef]

3. Tang, F.; Xu, Y.; Wang, H.; Bian, E.; Zhao, B. LncRNA-ATB in cancers: What do we know so far? Mol. Biol. Rep. 2020, 45, 4077-4086. [CrossRef]

4. Kuenzi, B.M.; Ideker, T. A census of pathway maps in cancer systems biology. Nat. Rev. Cancer 2020, 20, 233-246. [CrossRef]

5. Chabner, B.A.; Roberts, T.G. Timeline Chemotherapy and the war on cancer. Nat. Rev. Cancer 2005, 5, 65-72. [CrossRef]

6. Watermann, A.; Brieger, J. Mesoporous Silica Nanoparticles as Drug Delivery Vehicles in Cancer. Nanomaterials 2017, 7, 17. [CrossRef]

7. Ueno, Y.; Sonoda, S.; Suzuki, R.; Yokouchi, M.; Kawasoe, Y.; Tachibana, K.; Maruyama, K.; Sakamoto, T.; Komiya, S. Combination of ultrasound and bubble liposome enhance the effect of doxorubicin and inhibit murine osteosarcoma growth. Cancer Biol. Ther. 2011, 12, 270-277. [CrossRef]

8. Senapati, S.; Mahanta, A.K.; Kumar, S.; Maiti, P. Controlled drug delivery vehicles for cancer treatment and their performance. Signal Transduct. Target. Ther. 2018, 3, 19. [CrossRef]

9. Misra, R.; Acharya, S.; Sahoo, S.K. Cancer nanotechnology: Application of nanotechnology in cancer therapy. Drug Discov. Today 2010, 15, 842-850. [CrossRef]

10. Sinha, A.; Chakraborty, A.; Jana, N.R. Dextran-gated, multifunctional mesoporous nanoparticle for glucose-responsive and targeted drug delivery. ACS Appl. Mater. Interfaces 2014, 6, 22183-22191. [CrossRef]

11. Petros, R.A.; DeSimone, J.M. Strategies in the design of nanoparticles for therapeutic applications. Nat. Rev. Drug Discov. 2010, 9 , 615-627. [CrossRef]

12. Zhang, W.; Zhang, Z.; Zhang, Y. The application of carbon nanotubes in target drug delivery systems for cancer therapies. Nanoscale Res. Lett. 2011, 6, 555. [CrossRef]

13. Yadavalli, T.; Ramasamy, S.; Chandrasekaran, G.; Michael, I.; Therese, H.A.; Chennakesavulu, R. Dual responsive PNIPAMchitosan targeted magnetic nanopolymers for targeted drug delivery. J. Magn. Magn. Mater. 2015, 380, 315-320. [CrossRef]

14. Chen, W.; Glackin, C.A.; Horwitz, M.A.; Zink, J.I. Nanomachines and other caps on mesoporous silica nanoparticles for drug delivery. Acc. Chem. Res. 2019, 52, 1531-1542. [CrossRef]

15. Cheng, C.-A.; Deng, T.; Lin, F.-C.; Cai, Y.; Zink, J.I. Supramolecular nanomachines as stimuli-responsive gatekeepers on mesoporous silica nanoparticles for antibiotic and cancer drug delivery. Theranostics 2019, 9, 3341. [CrossRef]

16. Iturrioz-Rodríguez, N.; Correa-Duarte, M.A.; Fanarraga, M.L. Controlled drug delivery systems for cancer based on mesoporous silica nanoparticles. Int. J. Nanomed. 2019, 14, 3389. [CrossRef]

17. Slowing, I.I.; Vivero-Escoto, J.L.; Wu, C.-W.; Lin, V.S.-Y. Mesoporous silica nanoparticles as controlled release drug delivery and gene transfection carriers. Adv. Drug Deliv. Rev. 2008, 60, 1278-1288. [CrossRef]

18. Vivero-Escoto, J.L.; Slowing, I.I.; Trewyn, B.G.; Lin, V.S.Y. Mesoporous silica nanoparticles for intracellular controlled drug delivery. Small 2010, 6, 1952-1967. [CrossRef]

19. Tang, F.; Li, L.; Chen, D. Mesoporous silica nanoparticles: Synthesis, biocompatibility and drug delivery. Adv. Mater. 2012, 24, 1504-1534. [CrossRef] 
20. Lu, A.H.; Salabas, E.E.L.; Schüth, F. Magnetic nanoparticles: Synthesis, protection, functionalization, and application. Angezw. Chem. Int. Ed. 2007, 46, 1222-1244. [CrossRef]

21. Lu, J.; Ma, S.; Sun, J.; Xia, C.; Liu, C.; Wang, Z.; Zhao, X.; Gao, F.; Gong, Q.; Song, B. Manganese ferrite nanoparticle micellar nanocomposites as MRI contrast agent for liver imaging. Biomaterials 2009, 30, 2919-2928. [CrossRef]

22. Liong, M.; Lu, J.; Kovochich, M.; Xia, T.; Ruehm, S.; Nel, A.; Tamanoi, F.; Zink, J. Insert Table of Contents Graphic and Synopsis Here. ACS Nano 2008, 2, 889-896. [CrossRef]

23. Oh, J.M.; Choi, S.J.; Lee, G.E.; Han, S.H.; Choy, J.H. Inorganic drug-delivery nanovehicle conjugated with cancer-cell-specific ligand. Adv. Funct. Mater. 2009, 19, 1617-1624. [CrossRef]

24. El-Boubbou, K. Magnetic iron oxide nanoparticles as drug carriers: Clinical relevance. Nanomedicine 2018, 13, 953-971. [CrossRef]

25. Siminzar, P.; Omidi, Y.; Golchin, A.; Aghanejad, A.; Barar, J. Targeted delivery of doxorubicin by magnetic mesoporous silica nanoparticles armed with mucin-1 aptamer. J. Drug Target. 2020, 28, 92-101. [CrossRef]

26. Cai, D.; Liu, L.; Han, C.; Ma, X.; Qian, J.; Zhou, J.; Zhu, W. Cancer cell membrane-coated mesoporous silica loaded with superparamagnetic ferroferric oxide and Paclitaxel for the combination of Chemo/Magnetocaloric therapy on MDA-MB-231 cells. Sci. Rep. 2019, 9, 1. [CrossRef]

27. Wei, L.; Shi, D.; Zhou, Z.; Ye, P.; Wang, J.; Zhao, J.; Liu, L.; Chen, C.; Zhang, Y. Functionalized self-assembled monolayers on mesoporous silica nanoparticles with high surface coverage. Nanoscale Res. Lett. 2012, 7, 334. [CrossRef]

28. Torchilin, V.P. Multifunctional nanocarriers. Adv. Drug Deliv. Rev. 2006, 58, 1532-1555. [CrossRef]

29. Zhang, L.; Bei, H.P.; Piao, Y.; Wang, Y.; Yang, M.; Zhao, X. Polymer-Brush-Grafted Mesoporous Silica Nanoparticles for Triggered Drug Delivery. Chem. Phys. Chem. 2018, 19, 1956-1964. [CrossRef] [PubMed]

30. Ayres, N. Polymer brushes: Applications in biomaterials and nanotechnology. Polym. Chem. 2010, 1, 769-777. [CrossRef]

31. Feng, C.; Huang, X. Polymer brushes: Efficient synthesis and applications. Acc. Chem. Res. 2018, 51, 2314-2323. [CrossRef]

32. Conzatti, G.; Cavalie, S.; Combes, C.; Torrisani, J.; Carrere, N.; Tourrette, A. PNIPAM grafted surfaces through ATRP and RAFT polymerization: Chemistry and bioadhesion. Colloids Surf. B Biointerfaces 2017, 151, 143-155. [CrossRef]

33. Mai, B.T.; Fernandes, S.; Balakrishnan, P.B.; Pellegrino, T. Nanosystems based on magnetic nanoparticles and thermo-or pHresponsive polymers: An update and future perspectives. Acc. Chem. Res. 2018, 51, 999-1013. [CrossRef]

34. Pourjavadi, A.; Kohestanian, M.; Streb, C. pH and thermal dual-responsive poly (NIPAM-co-GMA)-coated magnetic nanoparticles via surface-initiated RAFT polymerization for controlled drug delivery. Mater. Sci. Eng. C 2020, 108, 110418. [CrossRef]

35. Kocak, G.; Tuncer, C.; Bütün, V. pH-Responsive polymers. Polym. Chem. 2017, 8, 144-176. [CrossRef]

36. Xu, L.; Li, H.-L.; Wang, L.-P. PH-Sensitive, Polymer Functionalized, Nonporous Silica Nanoparticles for Quercetin Controlled Release. Polymers 2019, 11, 2026. [CrossRef]

37. Alswieleh, A.M.; Beagan, A.M.; Alsheheri, B.M.; Alotaibi, K.M.; Alharthi, M.D.; Almeataq, M.S. Hybrid Mesoporous Silica Nanoparticles Grafted with 2-(tert-butylamino) ethyl Methacrylate-b-poly (ethylene Glycol) Methyl Ether Methacrylate Diblock Brushes as Drug Nanocarrier. Molecules 2020, 25, 195. [CrossRef]

38. Cheng, W.; Nie, J.; Xu, L.; Liang, C.; Peng, Y.; Liu, G.; Wang, T.; Mei, L.; Huang, L.; Zeng, X. pH-sensitive delivery vehicle based on folic acid-conjugated polydopamine-modified mesoporous silica nanoparticles for targeted cancer therapy. ACS Appl. Mater. Interfaces 2017, 9, 18462-18473. [CrossRef]

39. Manzano, M.; Vallet-Regí, M. Mesoporous silica nanoparticles in nanomedicine applications. J. Mater. Sci. Mater. Med. 2018, 29, 65. [CrossRef]

40. Niedermayer, S.; Weiss, V.; Herrmann, A.; Schmidt, A.; Datz, S.; Müller, K.; Wagner, E.; Bein, T.; Bräuchle, C. Multifunctional polymer-capped mesoporous silica nanoparticles for $\mathrm{pH}$-responsive targeted drug delivery. Nanoscale 2015, 7, 7953-7964. [CrossRef]

41. Park, J.; Park, S.S.; Jo, N.-J.; Ha, C.-S. Folic acid-polyethyleneimine functionalized mesoporous silica nanoparticles as a controlled release nanocarrier. J. Nanosci. Nanotechnol. 2019, 19, 6217-6224. [CrossRef]

42. Li, Y.; Wang, S.; Song, F.X.; Zhang, L.; Yang, W.; Wang, H.X.; Chen, Q.L. A pH-sensitive drug delivery system based on folic acid-targeted HBP-modified mesoporous silica nanoparticles for cancer therapy. Colloids Surf. A Physicochem. Eng. Asp. 2020, 590, 124470. [CrossRef]

43. Wu, H.; Liu, G.; Zhang, S.; Shi, J.; Zhang, L.; Chen, Y.; Chen, F.; Chen, H. Biocompatibility, MR imaging and targeted drug delivery of a rattle-type magnetic mesoporous silica nanosphere system conjugated with PEG and cancer-cell-specific ligands. J. Mater. Chem. 2011, 21, 3037-3045. [CrossRef]

44. Snoussi, Y.; Bastide, S.; Abderrabba, M.; Chehimi, M.M. Sonochemical synthesis of Fe3O4@ NH2-mesoporous silica@ Polypyrrole/Pd: A core/double shell nanocomposite for catalytic applications. Ultrason. Sonochem. 2018, 41, 551-561. [CrossRef]

45. Enache, D.F.; Vasile, E.; Simonescu, C.M.; Răzvan, A.; Nicolescu, A.; Nechifor, A.-C.; Oprea, O.; Pătescu, R.-E.; Onose, C.; Dumitru, F. Cysteine-functionalized silica-coated magnetite nanoparticles as potential nanoadsorbents. J. Solid State Chem. 2017, 253, 318-328. [CrossRef]

46. Wang, C.-G.; Goto, A. Solvent-selective reactions of alkyl iodide with sodium azide for radical generation and azide substitution and their application to one-pot synthesis of chain-end-functionalized polymers. J. Am. Chem. Soc. 2017, 139, 10551-10560. [CrossRef] 
47. Chapman, P.; Ducker, R.E.; Hurley, C.R.; Hobbs, J.K.; Leggett, G.J. Fabrication of two-component, brush-on-brush topographical microstructures by combination of atom-transfer radical polymerization with polymer end-functionalization and photopatterning. Langmuir 2015, 31, 5935-5944. [CrossRef]

48. Ji, J.; Wu, D.; Liu, L.; Chen, J.; Xu, Y. Preparation, characterization, and in vitro release of folic acid-conjugated chitosan nanoparticles loaded with methotrexate for targeted delivery. Polym. Bull. 2012, 68, 1707-1720. [CrossRef]

49. Bilalis, P.; Tziveleka, L.-A.; Varlas, S.; Iatrou, H. pH-Sensitive nanogates based on poly (L-histidine) for controlled drug release from mesoporous silica nanoparticles. Polym. Chem. 2016, 7, 1475-1485. [CrossRef]

50. Sun, J.-T.; Hong, C.-Y.; Pan, C.-Y. Fabrication of PDEAEMA-coated mesoporous silica nanoparticles and pH-responsive controlled release. J. Phys. Chem. C 2010, 114, 12481-12486. [CrossRef]

51. Chung, P.W.; Kumar, R.; Pruski, M.; Lin, V.S.Y. Temperature Responsive Solution Partition of Organic-Inorganic Hybrid Poly (N-isopropylacrylamide)-Coated Mesoporous Silica Nanospheres. Adv. Funct. Mater. 2008, 18, 1390-1398. [CrossRef]

52. Alswieleh, A.M.; Alshahrani, M.M.; Alzahrani, K.E.; Alghamdi, H.S.; Niazy, A.A.; Alsilme, A.S.; Beagan, A.M.; Alsheheri, B.M.; Alghamdi, A.A.; Almeataq, M.S. Surface modification of pH-responsive poly (2-(tert-butylamino) ethyl methacrylate) brushes grafted on mesoporous silica nanoparticles. Des. Monomers Polym. 2019, 22, 226-235. [CrossRef] [PubMed]

53. Beagan, A.; Lahmadi, S.; Alghamdi, A.; Halwani, M.; Almeataq, M.; Alhazaa, A.; Alotaibi, K.; Alswieleh, A. Glucosamine Modified the Surface of pH-Responsive Poly (2-(diethylamino) ethyl Methacrylate) Brushes Grafted on Hollow Mesoporous Silica Nanoparticles as Smart Nanocarrier. Polymers 2020, 12, 2749. [CrossRef] [PubMed] 